\title{
PENGARUH RETURN ON EQUITY (ROE) DAN EARNING PER SHARE (EPS) TERHADAP UNDERPRICING PADA SAHAM PERDANA DI BURSA EFEK INDONESIA TAHUN 2016
}

\author{
Kadek Melya Sintya Dewi ${ }^{1}$, Lulup Endah Tripalupi ${ }^{2}$, Iyus Akhmad Haris ${ }^{3}$ \\ Jurusan Pendidikan Ekonomi \\ Universitas Pendidikan Ganesha \\ Singaraja, Indonesia
}

e-mail: melyasintyadewi87@gmail.com¹, lulup tripalupi@yahoo.com², iyus.haris@gmail.com ${ }^{3}$

\begin{abstract}
Abstrak
Penelitian ini bertujuan untuk mengetahui secara parsial dan simultan pengaruh return on equity dan earning per share terhadap underpricing pada saham perdana di Bursa Efek Indonesia Tahun 2016. Jenis penelitian ini merupakan penelitian kuantitatif kausal. Data dikumpulkan dengan metode dokumentasi untuk memperoleh data sekunder berkaitan dengan laporan keuangan tahunan yang dimiliki oleh perusahaan berupa return on equity, earning per share dan underpricing. Teknik analisis data menggunakan analisis regresi linier berganda berbantuan program SPSS 24.0 for Windows. Hasil penelitian menunjukkan bahwa return on equity berpengaruh terhadap underpricing yang ditunjukkan dengan nilai uji t -3, 425 dengan tingkat signifikan $0,002<$ dari $\alpha=0,05$, earning per share berpengaruh terhadap underpricing yang ditunjukkan dengan nilai uji $t$ - 3,193 dengan tingkat signifikan $0,003<\alpha=0,05$; dan secara simultan return on equity dan earning per share berpengaruh terhadap underpricing yang ditunjukkan dengan nilai uji $F_{\text {hitung }}$ sebesar 17,986 dengan tingkat signifikan $0,000<\alpha=0,05$.
\end{abstract}

Kata kunci: return on equity, earning per share, underpricing.

\begin{abstract}
This research was aims to identify the partial and simultaneous effect of return on equity and earnings per share on underpricing at the first stock in Bursa Efek Indonesia 2016. The types of this research was causal quantitative research. The data collected by documentation method to obtain secondary data related to annual financial statements owned by company in the form of return on equity, earnings per share and underpricing. Data analysis technique using multiple linear regression analysis assisted program SPSS 24.0 for Windows. The results showed that return on equity effect on the underpricing as indicated by value of $t$ test $-3,425$ with significant level $0.002<\alpha=0.05$, earning per share effect on the underpricing as indicated by value of t test $-3,193$ with significant level $0.003<\alpha=0.05$, and simultaneously return on equity and earning per share effect on the underpricing as indicated by value of $F_{\text {hitung }} 17,986$ with significant level $0.000<\alpha=0.05$.
\end{abstract}

\section{PENDAHULUAN}

Pasar modal umumnya adalah tempat pertemuan antara penawaran dengan permintaan surat berharga. Ditempat inilah para pelaku pasar yaitu individu-individu atau badan usaha yang mempunyai kelebihan dana (surplus fund) melakukan investasi dalam surat berharga yang underpricing.

ditawarkan oleh emiten (Sunariyah, 2011). Pasar modal berperan dalam menunjang pelaksanaan pembangunan nasional dalam rangka meningkatkan pemerataan, pertumbuhan, dan stabilitas ekonomi nasional ke arah peningkatan kesejahteraan rakyat. Pasar modal juga menjalankan dua fungsi yaitu pertama 
sebagai sarana pendanaan atau usaha atau sebagai sarana bagi perusahaan untuk mendapatkan dana dari masyarakat investor. Kedua menjadi sarana bagi masyarakat untuk berinvestasi pada instrument keuangan (Martalena \& Malinda, 2011).

Pengertian pasar modal menurut Martalena \& Malinda (2011) pasar modal merupakan pasar untuk berbagi instrument keuangan jangka panjang yang bisa diperjualbelikan, baik surat utang (obligasi), ekuiti (saham), reksadana, instrument derivatif maupun instrument lainnya. Pasar modal merupakan sarana pendanaan bagi perusahaan maupun institusi lain, dan sebagai sarana bagi kegiatan berinvestasi, dengan demikian pasar modal memfasilitasi berbagai sarana dan prasarana kegiatan jual beli dan kegiatan terkait lainnya. Adapun pengertian pasar modal menurut Fahmi (2015:48), "pasar modal adalah tempat dimana berbagai pihak khususnya perusahaan menjual saham (stock) dan obligasi dengan tujuan dari hasil penjualan tersebut nantinya akan dipergunakan sebagai tambahan dana atau untuk memperkuat modal perusahaan". Menurut UU No. 21 tahun 2011 Tentang Otoritas Jasa Keuangan, "pasar modal adalah kegiatan yang bersangkutan dengan penawaran umum dan perdagangan efek. Perusahaan publik yang berkaitan dengan efek yang diterbitkannya, serta lembaga dan profesi yang berkaitan dengan efek". Menurut UU No. 8 Tahun 1995 Tentang Pasar Modal menyatakan, "pasar modal adalah kegiatan yang bersangkutan dengan penawaran umum dan perdagangan efek. Perusahaan publik yang berkaitan dengan efek".

Berdasarkan pengertian di atas, maka dapat diambil kesimpulan bahwa pasar modal merupakan mekanisme transaksi jual beli instrumen pasar modal jangka panjang antara penjual dan pembeli baik itu individu, koporasi maupun pemerintah. Pasar modal memiliki peran besar bagi perekonomian suatu Negara. Selain sebagai sarana untuk berinvestasi, pasar modal juga merupakan sumber dana bagi perusahaan. Sekaligus berperan dalam menjalakan kedua fungsinya yaitu fungsi ekonomi dan fungsi keuangan.
Pada umumnya setiap perusahaan mempunyai keinginan untuk memperluas usahanya, hal ini dilakukan dengan mengadakan ekspansi. Untuk melakukan ekspansi ini perusahaan memerlukan tambahan modal yang cukup besar. Dalam memenuhi kebutuhan dana yang cukup besar tersebut, seringkali dana yang diambil dari dalam perusahaan tidak cukup. Perusahaan dituntut untuk mencari solusi dalam menyelesaikan masalahnya. Dana yang didapatkan perusahaan diperoleh dari dalam maupun luar perusahaan. Pendanaan dari dalam perusahaan umumnya didapat dari laba yang ditahan perusahaan, sedangkan pendanaan dari luar pada umumnya berasal dari kreditur dan investor. Modal tersebut berupa hutang serta penanaman modal. Usaha yang dilakukan oleh manajemen untuk memperoleh dana besar salah satunya adalah mencari sumber dana dari luar perusahaan, yaitu di pasar modal dengan cara melakukan emisi saham.

Pasar modal berperan penting bagi pembangunan ekonomi sebagai salah satu sumber pembiayaan eksternal bagi dunia usaha dan tempat investasi bagi masyarakat. Pasar modal merupakan salah satu sarana guna memenuhi permintaan dan penawaran modal. Ditempat inilah para investor dapat melakukan investasi dengan cara pemilikan surat berharga bagi perusahaan.

Menurut Martalen \& Malinda (2011) menyatakan pasar modal merupakan pasar untuk berbagi instrument keuangan jangka panjang yang bisa diperjualbelikan, baik surat utang (obligasi), ekuiti (saham), reksadana, instrument derivatif maupun instrument lainnya. Pasar modal merupakan sarana pendanaan bagi perusahaan maupun institusi lain (mislanya pemerintah), dan sebagai sarana bagi kegiatan berinvestasi, dengan demikian pasar modal memfasilitasi berbagai sarana dan prasarana kegiatan jual beli dan kegiatan terkait lainnya.

Proses melakukan penawaran saham perdana di pasar modal dikenal dengan istilah go public. Perusahaan yang sudah go public menunjukkan bahwa perusahaan tersebut berubah dari perusahaan pribadi (private) menjadi perusahaan go public. 
Langkah pertama yang perlu dilakukan dalam proses go public yaitu dengan melakukan penawaran umum pnejualan di pasar perdana (Primary Market) yang disebut dengan Initial Public Offering. Kemudian saham dapat diperjual belikan di bursa efek atau disebut pasar sekunder (Secondary Market).

Permasalahan yang sering dihadapi perusahaan ketika melakukan penawaran saham perdana di pasar modal adalah besarnya harga saham perdana. Masalahnya penetapan harga saham perdana ini merupakan hal yang sulit ditentukan, karena sebelumnya tidak ada harga pasar yang dapat diobservasi untuk dipakai sebagai acuan penetapan harga penawaran dan juga karena masalah penetapan harga saham ini melibatkan kepentingan berbagai partisipan yang berbeda. Selain itu, masalah lain dalam penetapan harga saham perdana adalah kebanyakan dari perusahaan memiliki sedikit atau tidak ada pengalaman terhadap penetapan harga perdana. Sehingga bekerjasama dengan penjamin emisi (underwriter) yang sebelumnya telah ditentukan oleh perusahaan dalam menentukan harga saham yang akan dijual di pasar perdana, sedangkan harga di pasar sekunder ditentukan oleh mekanisme pasar yaitu permintaan dan penawaran.

Fenomena yang menarik dengan adanya penawaran saham perdana tersebut sering terjadinya underpricing yang menunjukkan bahwa harga penawaran saham perdana relatif lebih kecil dari harga saham penutupan hari pertama di pasar sekunder. Menurut Jogiyanto (2008) underpicing merupakan perbedaan antara harga penawaran perdana dengan harga penutupan saham perusahaan IPO di pasar sekunder pada hari pertama. Menggunakan harga saham penutupan hari pertama untuk memberikan tingkat underpricing yang lebih signifikan. Underpricing saham adalah suatu keadaan dimana efek yang dijual dibawah nilai likuidasinya atau nilai pasar yang seharusnya diterima oleh pemegang saham (Ang, 2010). Kondisi underpricing merugikan untuk perusahaan yang melakukan go public, karena dana yang diperoleh dari publik tidak maksimum. Para pemilik perusahaan menginginkan agar meminimalisasikan situasi underpricing, karena terjadinya underpricing akan menyebabkan transfer kemakmuran dari pemilik kepada para investor. Perusahaan yang meminimalisasikan underpricing akan mendapatkan keuntungan yang meningkat dalam bentuk laba untuk perusahaan dan investor, dengan hal tersebut penelitian ini menggunakan kemampuan perusahaan menghasilkan laba untuk mempengaruhi underpricing.

Berdasarkan hasil observasi penelitian ini dilakukan pada 37 perusahaan yang melakukan penawaran saham perdana di Bursa Efek Indonesia (BEI). Penurunan Return On Equity, Earning Per Share dan underpricing pada perusahaan Initial Public Offering di Bursa Efek Indonesia. Perusahaan tersebut mengalami penurunan tingkat pencapaian laba yang mengakibatkan laba perusahaan menjadi rendah, oleh karena itu menyebabkan terjadinya penurunan underpricing. $\mathrm{Hal}$ tersebut tidak sesuai dengan teori yang menyatakan bahwa perusahaan yang mengalami penurunan Return On Equity dan Earning Per Share akan mengakibatkan terjadinya underpricing, atau sebaliknya jika Return On Equity dan Earning Per Share meningkat maka yang terjadi adalah penurunan underpricing.

Menurut Syamsuddin (2011) Return On Equity merupakan suatu pengukuran dari penghasilan (income) yang tersedia bagi para pemilik perusahaan (baik pemegang saham biasa maupun preferen) atas modal yang mereka investasikan di dalam perusahaan. Nilai Return On Equity yang semakin tinggi akan menunjukkan bahwa perusahaan mampu menghasilkan laba dimasa yang akan datang dan laba merupakan informasi penting bagi investor sebagai pertimbangan dalam menanamkan modalnya. Menurut Jogiyanto (2000) bahwa semakin tinggi Return On Equity artinya kemampuan perusahaan untuk menghasilkan laba pada masa mendatang juga lebih tinggi. Hal ini dapat mengurangi ketidakpastian Initial Public Offering dalam menentukan harga saham yang wajar sehingga dapat menurunkan tingkat underpricing. Teori tersebut tidak sesuai dengan kenyataan pada saat obsevasi dimana pada tahun 2014-2016 underpricing 
mengalami penurunan dari $53,77 \%$ menjadi $36,93 \%$. Pada tahun 2014-2015 return on equity mengalami penurunan dari $89,64 \%$ menjadi $49,61 \%$, sedangkan pada tahun 2015-2016 return on equity mengalami peningkatan dari $49,61 \%$ menjadi $58,11 \%$. Menurut James \& Moira Chatton (2003) bahwa perusahaan yang mapan umumnya mempunyai rasio earning per share tinggi sedangkan perusahaan yang berusia muda mempunyai kecenderungan earning per share yang rendah. Sehingga semakin mapan perusahaan, semakin tinggi earning per share yang dimilikinya semakin rendah kemungkinan terjadinya underpricing, hal tersebut dikarenakan tingginya earning per share suatu perusahaan akan memberikan harapan investor untuk memperoleh keuntungan yang semakin besar dalam suatu periode tertentu dengan memiliki satu lembar saham, sehingga besarnya earning per share akan mengurangi ketidakpastian resiko dan harga saham perusahaan Initial Public Offering yang nantinya akan menurunkan tingkat underpricing. Darmadji \& Fakhrudin (2001) mengatakan bahwa yang diamksud dengan Earning Per Share adalah rasio yang menunjukkan seberapa besar keuntungan (return) yang diperoleh investor atau pemegang saham per saham. Sedangkan Tandelilin (2001) menyatakan Earning Per Share atau laba per lembar saham menunjukkan besarnya laba bersih perusahaan yang siap dibagikan bagi semua pemegang saham perusahaan atau jumlah uang yang dihasilkan (return) dari setiap lembar saham. Teori tersebut tidak sesuai dengan kenyataan pada saat observasi dimana pada tahun 2014-2016 underpricing mengalami penurunan dari $53,77 \%$ menjadi $36,93 \%$ dan earning per share mengalami penurunan dari Rp 1.253 menjadi Rp 376.

Menurut Soemarso (2003) bahwa pada saat melakukan penawaran umum, calon investor tidak sepenuhnya dapat membedakan perusahaan yang berkualitas baik dan buruk. Oleh karena itu, emiten dan penjamin emisi dengan sengaja akan memberikan sinyal kepada pasar yang merupakan sinyal positif yang berusaha diberikan oleh emiten guna menunjukkan kualitas perusahaan pada saat Initial Public
Offering. Kualitas perusahan yang digunakan sebagai sinyal tersebut akan mempengaruhi terjadinya underpricing. Kualitas perusahaan tersebut berupa kemampuan perusahaan untuk memperoleh laba, hal tersebut dapat berupa Return On Equity, ROI, ROA, PBV, dan Earning Per Share. Perusahaan akan memberikan informasi kepada investor untuk membeli saham dan menanamkan modalnya. Sehingga Return On Equity, ROI, ROA, PBV dan Earning Per Share mempengaruhi terjadinya tingkat underpricing.

\section{METODE}

Penelitian ini merupakan jenis penelitian kuantitatif kausal. Penelitian kausal adalah penelitian yang menunjukkan hubungan variabel bebas dengan variabel terikat (Sugiyono, 2009). Terdapat tiga variabel yang digunakan dalam penelitian ini, yaitu 2 (dua) variabel bebas dan 1 (satu) variabel terikat. Variabel bebas dalam penelitian ini adalah adalah return on equity $\left(X_{1}\right)$ dan earning per share $\left(X_{2}\right)$, sedangkan variabel terikat dalam penelitian ini adalah underpricing (Y). Return on equity adalah mengukur kemampuan perusahaan memperoleh laba yang tersedia bagi pemegang saham perusahaan (Sartono,2008).

Earning per share adalah rasio yang menunjukkan seberapa besar keuntungan (return) yang diperoleh investor atau pemegang saham per saham (Darmadji \& Fakhrudin, 2001). Underpricing saham adalah suatu keadaan dimana efek yang dijual di bawah nilai likuidasinya atau nilai pasar yang seharusnya diterima oleh pemegang saham (Ang, 2010).

Populasi adalah wilayah generalisasi yang terdiri atas objek atau subjek yang mempunyai kuantitas dan karakteristik tertentu yang ditetapkan oleh peneliti untuk dipelajari dan kemudian ditarik kesimpulannya (Sugiyono, 2009). Populasi meliputi seluruh karakteristik yang dimiliki oleh subjek atau objek dari penelitian. Adapun populasi dalam penelitian ini adalah perusahaan-perusahaan yang melakukan penawaran saham perdana (IPO) di Bursa Efek Indonesia (BEI) tahun 2016 yang berjumlah 75 perusahaan. 
Sampel adalah bagian dari jumlah dan karakteristik yang dimiliki oleh populasi tersebut (Sugiyono,2009). Dalam menentukan sampel peneliti menggunakan purposive sampling yang merupakan teknik penentuan sampel dengan pertimbangan tersebut. Alasan pemilihan metode purposive sampling karena penelitian ini menggunakan data laporan keuangan yang dipilih berdasarkan lima kriteria yang telah ditentukan. Adapun kriteria dalam pemilihan sampel adalah pertama perusahaan yang melakukan Initial Public Offering tahun 2016, kedua perusahaan yang mengalami underpricing tahun 2016, ketiga perusahaan menerbitkan laporan keuangan dengan menggunakan tahun buku yang berakhir tanggal 31 Desember tahun terakhir sebelum melakukan Initial Public Offering (IPO), keempat data perusahaan khususnya return on equity dan earning per share tidak memiliki nilai negatif, dan kelima perusahaan yang datanya lengkap tahun 2016. Berdasarkan ketentuan di atas maka sampel yang digunakan dalam penelitian ini berjumlah 37 perusahaan yang melakukan penawaran saham perdana atau IPO di Bursa efek Indonesia Sektor Jasa dengan memiliki data keuangan terlengkap.

Jenis data penelitian ini adalah data kuantitatif, yaitu data berupa angka-angka pada laporan keuangan perusahaan yang diperoleh dari situs resmi Bursa Efek Indonesia yaitu melalui www.idx.co.id dan www.sahamok.com. Data penelitian ini bersumber dari data sekunder. Data sekunder, yaitu sumber data yang diperoleh melalui media perantara atau secara tidak langsung, artinya data-data tersebut berupa catatan, bukti, arsip atau dokumen. Data yang digunakan diperoleh dari laporan keuangan tahunan di Indonesia Stock Exchange (IDX) tahun 2016 dan data Initial Public Offering di Real Time Market

Information tahun 2016.

Metode pengumpulan data yang digunakan dalam penelitian ini adalah metode dokumentasi. Metode dokumentasi digunakan untuk memperoleh data laporan keuangan tahunan yang dimiliki oleh perusahaan berupa return on equity, earning per share dan underpricig.

Teknik analisis data yang digunakan untuk menguji hipotesis yang diajukan, yaitu untuk mengetahui ada tidaknya hubungan antara variabel bebas (X) dengan variabel terikat $(Y)$ adalah uji t dan uji $F$. Uji $t$ digunakan untuk mengetahui pengaruh return on equity $\left(X_{1}\right)$ terhadap underpricing $(\mathrm{Y})$, pengaruh earning per share $\left(X_{2}\right)$ terhadap underpricing $(Y)$. Pengujian ini dilakukan dengan menggunakan significance level 0,05 $(\alpha=$ $5 \%$ ). Jika nilai signifikan > 0,05 maka $\mathrm{H}_{0}$ ditolak. Ini berarti bahwa secara parsial variabel independen tersebut tidak mempunyai pengaruh signifikan terhadap variabel dependen. Jika signifikan $<0,05$, maka $\mathrm{H}_{0}$ diterima. Hal ini berarti secara parsial variabel independen tersebut mempunyai pengaruh yang signifikan terhadap variabel dependen. Uji $F$ digunakan untuk mengetahui yaitu pengaruh return on equity $\left(\mathrm{X}_{1}\right)$ dan pengaruh earning per share $\left(X_{2}\right)$ secara bersama-sama terhadap underpricing $(\mathrm{Y})$ pada saham perdana di bursa efek indonesia. Pengujian dilakukan dengan menggunakan significance level 0,05 ( $\alpha=$ $5 \%$ ). Ketentuan penerimaan atau penolakan hipotesis adalah jika nilai signifikansi > 0,05 maka dapat disimpulkan bahwa $\mathrm{H}_{0}$ diterima. Hal ini berarti bahwa secara simultan kedua variabel independen tersebut tidak mempunyai pengaruh yang signifikan terhadap variabel dependen. Jika nilai signifikansi $<0,05$ maka dapat disimpulkan bahwa $\mathrm{H}_{0}$ ditolak. Hal ini berarti secara simultan kedua variabel independen mempunyai pengaruh signifikan terhadap variabel dependen.

Analisis regresi linier berganda digunakan untuk mengetahui pengaruh antara dua variabel bebas atau lebih terhadap variabel terikat (Sugiyono, 2011). Dari hasil analisis regresi linier berganda dapat diketahui persamaan garis regresi sebagai berikut.

$$
Y=a+\beta_{1} X_{1}+\beta_{2} X_{2}
$$

Keterangan:

$\mathrm{Y}=$ Underpricing

$\alpha=$ Koefisien konstanta

$\beta=$ Koefisien regresi

$\mathrm{X}_{1}=$ Return on equity

$\mathrm{X}_{2}=$ Earning per share

Sebelum dilakukan pengujian analisis regresi linear berganda, maka dilakukan uji 
asumsi klasik, yang terdiri dari uji normalitas, uji heteroskedastisitas, uji multikolinearitas, dan uji autokorelasi.

\section{HASIL DAN PEMBAHASAN Hasil}

Untuk mengetahui pengaruh return on equity secara parsial terhadap underpricing pada penawaran saham perdana di bursa efek Indonesia, dilakukan analisis $t_{\text {test }}$ dengan menggunakan SPSS 24 for windows. Hasil analisis tersebut menunjukkan bahwa pengaruh return on equity terhadap underpricing pada saham perdana di Bursa Efek Indonesia pada tahun 2016 dapat dilihat pada tabel 1 berikut.

Tabel 1. Hasil Uji t untuk Pengaruh Return On Equity Terhadap Underpricing

\begin{tabular}{|c|c|c|c|c|c|c|}
\hline & \multirow{3}{*}{ Model } & \multicolumn{2}{|c|}{ Unstandardized } & \multirow{2}{*}{$\frac{\text { Standardized }}{\text { Coefficients }}$} & \\
\hline & & & ents & & $\mathrm{t}$ & Sig. \\
\hline & & B & Std. Error & Beta & & \\
\hline 1 & (Constant) & 52,430 & 5,626 & & 9,320 & 0,000 \\
\hline & $\begin{array}{l}\text { Return on } \\
\text { equity }\end{array}$ & $-2,008$ & 0,586 & $-0,445$ & $-3,425$ & 0,002 \\
\hline
\end{tabular}

a. Dependent Variable: Underpricing

Berdasarkan hasil analisis pada tabel 1 dapat diketahui bahwa variabel return on equity diperoleh nilai $\mathrm{t}$ sebesar $-3,425$. Tingkat signifikansi menunjukkan 0,002 yang lebih kecil dari taraf signifikansi 0,05 . Dengan demikian hipotesis $\mathrm{H}_{0}$ ditolak, hal ini dapat disimpulkan bahwa return on equity berpengaruh negatif dan signifikan terhadap underpricing pada saham perdana di bursa efek Indonesia.
Untuk mengetahui pengaruh earning per share secara parsial terhadap underpricing pada saham perdana di bursa efek Indonesia, dilakukan analisis $t_{\text {test }}$ dengan menggunakan SPSS 24 for windows. Hasil analisis tersebut menunjukkan bahwa pengaruh earning per share terhadap underpricing pada saham perdana di bursa efek Indonesia dapat dilihat pada tabel 2 .

Tabel 2. Hasil Uji t untuk Pengaruh Earning Per Share Terhadap Underpricing

\begin{tabular}{|c|c|c|c|c|c|c|}
\hline \multirow{3}{*}{\multicolumn{2}{|c|}{ Model }} & \multirow{2}{*}{\multicolumn{2}{|c|}{ Coefficients }} & Standardized & & \\
\hline & & & & \multirow{2}{*}{$\begin{array}{c}\text { Coefficients } \\
\text { Beta }\end{array}$} & \multirow[t]{2}{*}{$\mathrm{t}$} & \multirow[t]{2}{*}{ Sig. } \\
\hline & & B & Std. Error & & & \\
\hline \multirow[t]{2}{*}{1} & (Constant) & 52,430 & 5,626 & & 9,320 & 0,000 \\
\hline & Return on & $-0,193$ & 0,060 & $-0,415$ & $-3,193$ & 0,003 \\
\hline
\end{tabular}

a. Dependent Variable: Underpricing

Berdasarkan hasil analisis pada tabel

2 dapat diketahui bahwa variabel earning per share diperoleh nilai t sebesar $-3,193$. Tingkat signifikansi menunjukkan 0,003 yang lebih kecil dari taraf signifikansi 0,05 . Dengan demikian hipotesis $\mathrm{H}_{0}$ ditolak hal ini dapat disimpulkan bahwa earning per share berpengaruh negatif dan signifikan terhadap underpricing.

Untuk mengetahui pengaruh secara simultan return on equity dan earning per Tabel 3. Hasil Uji F Pengaruh Return On Equity dan Earning Per Share Terhadap Underpricing share terhadap underpricing pada saham perdana di bursa efek Indonesia dilakukan dengan menggunakan uji statistik $F$ dengan program SPSS 24 for windows. Uji $F$ menunjukkan variabel bebas, yaitu return on equity $\left(\mathrm{X}_{1}\right)$ dan earning per share $\left(\mathrm{X}_{2}\right)$ dimasukkan ke dalam model yang mempunyai pengaruh terhadap variabel terikat yaitu underpricing (Y). Hasil uji statistik $\mathrm{F}$ tersebut dapat dilihat pada tabel 3. 


\begin{tabular}{|c|c|c|c|c|c|c|}
\hline \multicolumn{7}{|c|}{ ANOVA } \\
\hline & Model & Sum of & $d f$ & Mean & $\mathrm{F}$ & Sig. \\
\hline \multirow{3}{*}{1} & Rearession & 12270.681 & 2 & 6135.341 & 17986 & 0.000 \\
\hline & Residual & 11598,314 & 34 & 341,127 & & \\
\hline & Total & 23868,995 & 36 & & & \\
\hline
\end{tabular}

a. Dependent Variable: Underpricing

b. Predictors: (Constant), Earning Per Share, Return On Equity

Berdasarkan hasil analisis uji statsistik

$F$ pada tabel 3 diperoleh nilai $F$ hitung sebesar 17,986 dengan signifikansi sebesar 0,000 . Nilai signifikansi 0,000 lebih kecil dari 0,05 (sig. < 0,05). Hal ini berarti bahwa secara simultan return on equity dan earning per share berpengaruh signifikan terhadap underpricing pada saham perdana di Bursa Efek Indonesia Tahun 2016.
Berdasarkan hasil analisis regresi linier berganda, dapat diketahui persamaan garis regresi untuk mengetahui pengaruh return on equity dan earning per share terhadap underpricing pada saham perdana di Bursa Efek Indonesia Tahun 2016 dengan menggunakan analisis koefisien beta. Hasil perhitungan konstanta dan koefisien beta dapat dilihat pada tabel 4 .

Tabel 4. Hasil Analisis Koefisien Beta

\begin{tabular}{|c|c|c|c|c|c|c|}
\hline & \multirow[t]{2}{*}{ Model } & \multicolumn{2}{|c|}{$\begin{array}{l}\text { Unstandardized } \\
\text { Coefficients }\end{array}$} & \multirow{2}{*}{$\begin{array}{c}\text { Standardized } \\
\text { Coefficients } \\
\text { Beta }\end{array}$} & \multirow[t]{2}{*}{$t$} & \multirow[t]{2}{*}{ Sig. } \\
\hline & & $\mathrm{B}$ & Std. Error & & & \\
\hline \multirow[t]{3}{*}{1} & (Constant) & 52,430 & 5,626 & & 9,320 & 0,000 \\
\hline & $\begin{array}{l}\text { Return on } \\
\text { equity }\end{array}$ & $-2,008$ & 0,586 & $-0,445$ & $-3,425$ & 0,002 \\
\hline & $\begin{array}{l}\text { Earning per } \\
\text { share }\end{array}$ & $-0,193$ & 0,060 & $-0,415$ & $-3,193$ & 0,003 \\
\hline
\end{tabular}

a. Dependent Variable: Underpricing

Berdasarkan perhitungan regresi linier berganda pada tabel 4, maka didapat hasil persamaan regresi sebagai berikut.

$$
Y=52,430-2,008 X_{1}-0,193 X_{2}
$$

Berdasarkan model persamaan regresi yang terbentuk, dapat diinterpretasikan hasil bahwa konstanta sebesar 52,430 menunjukan jika variabel return on equity $\left(\mathrm{X}_{1}\right)$ dan earning per share $\left(X_{2}\right)$ bernilai konstan atau nol, maka variabel underpricing ( $\mathrm{Y}$ ) memiliki nilai positif sebesar 52,430. Selanjutnya, variabel return on equity $\left(\mathrm{X}_{1}\right)$ memiliki koefisien negatif sebesar $-2,008$ dan variabel earning per share $\left(\mathrm{X}_{2}\right)$ memiliki koefisien negatif sebesar $-0,193$. Nilai koefisien regresi yang negatif menunjukkan bahwa return on equity $\left(\mathrm{X}_{1}\right)$ dan earning per share $\left(X_{2}\right)$ berpengaruh negatif terhadap underpricing $(\mathrm{Y})$. Hal ini menggambarkan bahwa peningkatan return on equity $\left(\mathrm{X}_{1}\right)$ dan earning per share $\left(\mathrm{X}_{2}\right)$ sebesar satu satuan akan dapat menurunkan underpricing $(\mathrm{Y})$ sebesar nilai koefisien beta masing-masing variabel bebas dikalikan dengan besar kenaikan yang terjadi. Misalnya, setiap terjadi kenaikan return on equity $\left(\mathrm{X}_{1}\right)$ sebesar satu satuan, maka akan menurunkan underpricing $(Y)$ sebesar 2,008 dan setiap terjadi kenaikan earning per share $\left(\mathrm{X}_{2}\right)$ sebesar satu satuan, maka akan menurunkan underpricing $(\mathrm{Y})$ sebesar 0,193 . Hal ini menunjukkan bahwa semakin tinggi return on equity yang diberikan dan earning per share, maka semakin rendah underpricing. Sebaliknya, semakin rendah return on equity yang diberikan dan earning per share karyawan, maka semakin tinggi underpricing.

\section{Pembahasan}

Berdasarkan hasil penelitian dapat 
ditunjukkan bahwa return on equity berpengaruh negatif dan signifikan terhadap underpricing, earning per share berpengaruh negatif dan signifikan terhadap underpricing, dan secara simultan return on equity dan earning per share berpengaruh signifikan terhadap underpricing pada saham perdana di bursa efek Indonesia tahun 2016. Sesuai dengan pendapat Kasmir (2012) menyatakan bahwa hasil pengembalian ekuitas atau return on equity atau rentabilitas modal sendiri merupakan rasio untuk mengukur laba bersih sesudah pajak dengan modal sendiri. Secara umum tentu saja semakin tinggi return atau penghasilan yang diperoleh semakin baik kedudukan pemilik perusahaan. Pendapat tersebut sesuai dengan hasil yang diperoleh peneliti yang menyatakan adanya pengaruh return on equity terhadap underpricing. Return on equity merupakan salah satu rasio profibalitas, yaitu rasio yang menunjukkan seberapa efektifnya perusahaan beroperasi sehingga menghasilkan keuntungan atau laba bagi perusahaan dari modal yang dimilikinya. Profitabilitas yang tinggi dapat meminimalisir tingkat underpricing karena penjamin emisi yakin untuk menjual saham perusahaan dengan harga yang tinggi dan yakin semua saham yang ditawarkan terjual. Profitabilitas yang tinggi dari suatu perusahaan akan mengurangi ketidakpastian bagi investor sehingga akan menurunkan tingkat underpricing. Hasil penelitian ini didukung oleh penelitian yang dilakukan oleh Permatasari (2014) yang menyatakan bahwa variabel return on equity berpengaruh signifikan terhadap underpricing.

Penelitian mengenai pengaruh dari variabel earning per share terhadap underpricing menunjukan bahwa berpengaruh signifikan. Hasil penelitian tersebut sesuai dengan pernyataan Sofyan (2007), earning per share digunakan untuk mengukur keberhasilan manajemen dalam mencapai keuntungan bagi pemilik perusahaan. Rasio earning per share rendah berarti manajemen tidak dapat menghasilkan kinerja yang baik dengan memperhatikan pendapatan-pendapatan yang diperoleh perusahaan tersebut. Rasio earning per share yang tinggi berarti suatu perusahaan sudah mapan (mature) karena dapat memberikan laba kepada investor dalam jumlah besar. Earning per share merupakan proxy laba per lembar saham perusahaan yang diharapkan dapat memberikan gambaran bagi investor mengenai bagian keuntungan yang dapat diperoleh dalam suatu periode tertentu dengan memiliki suatu saham. Profitabilitas yang tinggi dari suatu perusahaan akan mengurangi ketidakpastian bagi investor sehingga akan menurunkan tingkat underpricing. Hasil penelitian ini didukung oleh penelitian yang dilakukan oleh Sari (2011) yang menyatakan bahwa variabel earning per share berpengaruh signifikan terhadap underpricing.

Hasil penelitian mengenai pengaruh dari variabel return on equity dan earning per share terhadap underpricing pada penawaran saham perdana di bursa efek Indonesia berpengaruh secara simultan. $\mathrm{Hal}$ ini sesuai dengan pernyataan Soemarso (2003) bahwa kualitas perusahaan dalam memperoleh laba dapat berupa ROE, ROI, ROA, PBV dan EPS. ROE, ROI, PBV dan EPS perusahaan akan memberikan informasi kepada investor untuk membeli saham dan menanamkan modalnya. Sehingga, ROE, ROI, ROA, PBV dan EPS mempengaruhi terjadinya tingkat underpricing. Karena adanya faktor-faktor lainnya yang dapat meningkatkan underpricing selain pendapat yang dinyatakan Soemarso.

\section{SIMPULAN DAN SARAN Simpulan}

Berdasarkan hasil analisis data dan pembahasan hasil penelitian maka dapat ditarik simpulan sebagai berikut. Pertama terdapat pengaruh return on equity terhadap underpricing pada penawaran saham perdana di Bursa Efek Indonesia Tahun 2016, yang ditunjukkan dengan nilai uji $t$ sebesar $-3,425$ dengan tingkat signifikan 0,002 yang lebih kecil dari $\alpha=$ 0,05 . Kedua terdapat pengaruh earning per share terhadap underpricing pada penawaran saham perdana di Bursa Efek Indonesia Tahun 2016, yang ditunjukkan dengan nilai uji t sebesar -3,193 dengan tingkat signifikan 0,003 yang lebih kecil dari $\alpha=0,05$. Ketiga terdapat pengaruh return 
on equity dan earning per share terhadap underpricing pada penawaran saham perdana di Bursa Efek Indonesia Tahun 2016, yang ditunjukkan dengan nilai uji $F_{\text {hitung }}$ sebesar 17,986 dengan signifikansi sebesar 0,000 yang lebih kecil dari $\alpha=$ 0,05 .

\section{Saran}

Berdasarkan simpulan diatas, maka dapat dikemukakan beberapa saran sebagai berikut. Pertama bagi manajemen perusahaan yang terdaftar di Bursa Efek Indonesia Tahun 2016 disarankan mempertimbangkan return on equity dan earning per share untuk meminimalisir underpricing pada saham perdana. Hal ini diharapkan dapat menghasilkan laba bagi perusahaan dan investor, sehingga dapat membawa perusahaan ke arah lebih baik dalam harga penawaran saham perdana relatif menjadi lebih besar dari harga saham penutupan hari pertama di pasar sekunder. Kedua bagi peneliti selanjutnya yang tertarik untuk mengkaji aspek yang serupa mengenai pengaruh return on equity dan earning per share terhadap underpricing pada saham perdana diharapkan untuk mengembangkan penelitian ini dengan menggunakan populasi dan sampel yang lebih luas agar hasil penelitian lebih teruji keandalannya.

\section{DAFTAR PUSTAKA}

Ang, Robert. 2010. Buku Pintar Modal Indonesia. Jakarta: Mediasoft Indonesia.

Darmadji, T \& Fakhrudin M. H. 2001. Pasar Modal di Ind snesia Pendekatan Tanya Jawab. Jakarta: Salemba Empat.

Fahmi, Irham. 2015. Manajemen Investasi. Jakarta: Salemba Empat.

Jogiyanto, Hartono. 2000. Teori Portofolio dan Analisis Investasi. Edisi Pertama. Yogyakarta: BPFE Yogyakarta.

Jogiyanto, Hartono. 2008. Teori Portofolio dan Analisis Investasi. Edisi Kelima. Yogyakarta: BPFE Yogyakarta.
James, O. Gill \& Moira Chatton. 2003. Memahami laporan Keuangan. Jakarta: Penerbit PPM.

Kasmir. 2012. Analisis Laporan Keuangan. Jakarta: PT Raja Grafindo Persada.

Mamduh M. Hanafi dan Abdul Halim. 2003. Analisis Laporan Keuangan: Yogyakarta. AMP-YKPN.

Martalena \& Malinda. 2011. Pengantar Pasar Modal. Edisi Pertama. Yogyakarta: Andi

Permatasi, venti eka. 2014. Analisis Pengaruh Informasi Keuangan dan Non Keuangan Terhadap Tingkat Underpricing Pada Perusahaan Non Keuangan Yang Melakukan Inilital Public Offering Di Busa Efek Indonesia Periode 2008-2013. Skripsi tidak diterbitkan. Fakultas Ekonomika Dan Bisnis, Universitas Diponegoro.

Sari, Ardhini Yuma. 2011. Analisis FaktorFaktor Yang Mempengaruhi Underpricing Pada Penawaran Umum Perdana (Studi Kasus Pada Perusahaan Non Keuangan Yang Go Publik Di Bursa Efek Indonesia tahun 2006-2010). Skripsi tidak diterbitkan. Fakultas Ekonomi, Universitas Diponegoro.

Sartono, Agus. 2008. Manajemen Keuangan Teori dan Aplikasi Edisi Empat. Yogyakarta: BPFE.

Siamat, Dahlan. 2004. Manajemen Lembaga Keuangan. Edisi Ke-4. Jakarta: Lembaga Penerbit Fakultas Ekonomi Universitas Indonesia.

Soemarso, S.R. 2003. Akuntansi Suatu Pengantar. Edisi ke-5 Buku Satu. Jakarta: Salemba Empat.

Sofyan, Syafri Harahap. 2007. Analisis Kritis atas Laporan Keuangan. Jakarta: PT. Raja Grafindo Persada.

Sugiyono. 2009. Metode penelitian Bisnis. Bandung: Alfabeta.

Sugiyono. 2011. Metode Penelitian Kuantitatif, Kualitatif dan $R \& D$. Bandung: 
p-ISSN : 2599-1418

e-ISSN : 2599-1426
Jurnal Pendidikan Ekonomi Undiksha Volume 10 No. 1 Tahun 2018

Sunariyah. 2011. Pengantar Pasar Modal. Yogyakarta: UPP STIM YKPN.

Syamsuddin, Lukman. 2004. Manajmen Keuangan Perusahaan. Jakarta: PT Raja Grafindo Persada.

Syamsuddin, Lukman. 2011. Manajemen Keuangan Perusahaan: Konsep Aplikasi, dalam Perencanaan, Pengawasan, dan Pengambilan Keputusan. Jakarta: PT. Raja Grafindo Persada.

Tandelilin, Eduardus. 2001. Analisis Investasi dan Manajemen Portofolio. Yogyakarta: BPFE Yogyakarta.

Undang-Undang No.8 Tahun 1995 tentang Pasar Modal.

Undang-Undang No. 21 Tahun 2011 tentang Otoritas Jasa Keuangan. 